\title{
Investing in "success" as Māori and Pacific: The collaborative development of Ngā Tau Tuangahuru, a longitudinal evaluation study
}

Rachael Trotman, Fiona Cram, Tanya Samu, Moi Becroft, Reremoana Theodore, and Tony Trinick

In 2006, the ASB Community Trust (now Foundation North) committed \$20 million to raising Māori and Pacific educational achievement in Auckland and Northland. Ten providers were funded through the Māori and Pacific Education Initiative (MPEI) to implement innovative educational approaches in their communities. Evaluators developed an overarching MPEI theory of change and assessed this initial phase of MPEI as highly effective. Foundation North has since committed to Ngā Tau Tuangahuru ("Looking beyond for ten more years"), a 10-year longitudinal evaluation study involving students and families from five MPEI provider communities. This study will test and deepen the MPEI theory of change, particularly from students' and families' perspectives. This article describes how the study team worked with six MPEI providers over 2 years to collaboratively design this study. Agreement was reached that the study will explore what 'success' looks like for Māori and Pacific students and their families, and what supports this success at individual, family, educational, and community levels. Community 
researchers have been recruited in consultation with the MPEI providers, to interview up to 100 Māori and Pacific students aged 8 to 16 years, and their families. The first round of interviews took place in 2017 and there will be three further interviews by 2025 to explore student and family journeys. Key ingredients of the study to date include relationships, resourcing, and time to collaboratively develop the study, and the transdisciplinary team.

Foundation North (formerly the ASB Community Trust) is a philanthropic organisation that has grown a reputation for being bold and inventive in its intention to enable social change and innovation. The purpose of this article is to describe the development of a longitudinal evaluation study of the Foundation's Māori and Pacific Education Initiative (MPEI). An overview of MPEI is provided, including the emergence of the longitudinal evaluation study, before the collaborative development of this study is described. Section 3 explains the evaluative aspects of the study, and a final discussion synthesises the key enablers of the study to date.

\section{Māori and Pacific Education Initiative-Initial phase}

In 2006, the ASB Community Trust committed $\$ 20$ million to raising Māori and Pacific educational achievement in Auckland and Northland. The aim was "to find and fund innovative proposals to address the serious problem of educational underachievement among Māori and Pacific communities" (MPEI Contributors \& Hancock, 2012a, p. 12).

The Māori and Pacific Education Initiative (MPEI) was designed collaboratively by members of Māori and Pacific communities who had an interest or expertise in education and community development. Manuka Henare reflected that those involved during these early stages of MPEI were not rushed in their decision making. Time 
was taken to share ideas and build trust, so that participants felt respected and listened to.

Our journey together was like a long symposium that embraced relationship building, companionship, conviviality and important dialogue. Māori and Pacific Island peoples believe that when the process is good, you bring the future into the present (Manuka Henare, in MPEI Contributors \& Hancock, 2012a, p. 11).

The result was a high engagement approach within MPEI, investing in ten community-led education initiatives in Auckland and Northland. ${ }^{1}$ This approach was founded on trusting relationships of support and co-creation, and included fundee evaluation capacity building (Kinnect Group \& Foundation North, 2016a, p. 14).

Given their innovative and evolving nature, developmental evaluation was used to evaluate the approach of each provider and the overall MPEI high engagement model (Kinnect Group \& Foundation North Learning Series, 2016c). ${ }^{2}$ The evaluation found that MPEI was an effective and valuable investment and that " $[\mathrm{t}]$ he MPEI projects have demonstrated that Māori and Pacific communities are capable of creating change across a wide spectrum of vulnerability" (Kinnect Group \& Foundation North, 2016b, p. 10). The MPEI providers have been at least as successful or have outperformed other similar providers in terms of comparable educational achievement, including literacy and numeracy, and six of the MPEI-funded providers have seen their operations expanded or scaled up. The economic return from Foundation North's MPEI investment is expected be evident within 5 years (Kinnect Group \& Foundation North, 2016a). ${ }^{3}$

Together with Foundation North staff, trustees, and the MPEI providers, the Kinnect Group facilitated a "theory of change" for Māori and Pacific educational success (see Figure 1). These elements of success align with other research findings, for example, that higher achievement and success for Māori and Pacific students occurs when 
they can see themselves in the curriculum (Bishop, Berryman, Tiakiwai \& Richardson, 2003; Gorinski \& Abernethy, 2007; Fletcher, Parkhill, Fa'afoi, Tufulasi Taleni \& O'Regan, 2009). The MPEI theory of change also supports recent educational strategies for Māori and Pacific learners (Ministry of Education, 2013a, 2013b).

Success as Māori and Pasifika

Pride, sense of identity

Engagement in wider whānau, community, and church life

Leadership and service

Educational and economic success

\section{Cultural legitimacy}

Positive reinforcement of cultural identity, language, practices, values, and models

Relationships matter and wellbeing

Resilient whānau—able to adapt and respond

Aroha, care, and trust

My whānau/ aiga know how to support me

Community-driven with project sovereignty

By Māori, for Māori, as Māori

By Pacific, for Pacific, as Pacific

Figure 1. A Theory of Change for Māori and Pacific Educational Success 
Research has identified the key role played by students' families and communities as partners in the education process (Gorinski \& Fraser, 2006). Moreover, Māori and Pacific students value educational achievement as a communal good as well as a personal benefit and are often motivated by their desire to use their education to contribute to their communities (Macfarlane, Webber, Cookson-Cox, \& McRae, 2014). There are growing calls for research to focus on how to amplify the strengths and successes of Māori and Pacific students and families, and to move away from mainstream deficit perspectives of Māori and Pacific educational achievement (Gorinski \& Abernethy, 2007). As noted by the MPEI evaluators, the evidence-informed elements of Māori and Pacific student success described above "are still not yet well understood in mainstream education contexts" (Kinnect Group \& Foundation North, 2016b, p. 6).

\section{MPEI-Next phase}

Following the completion of the initial phase of MPEI, Foundation North has funded a longitudinal evaluation study of MPEI, looking at what happens for children, young people and their families over time, linked to their involvement in MPEI-funded initiatives. In late 2016, the study was given the name Ngā Tau Tuangahuru, which translates to "looking beyond for ten more years", by Foundation North kaumātua Kevin Prime. This study was developed in a similar way to the MPEI initiatives preceding it, in an unhurried way founded on hospitality, trust building, sharing, and storytelling.

Members of Foundation North's Māori and Pacific Committee (a subcommittee of the Foundation's Board) first mooted the idea of an MPEI longitudinal evaluation study in 2013. They expressed interest in tracking longer term outcomes from MPEI, and curiosity about the journeys of these children, young people and their families over time. The success of the individual MPEI initiatives and the 
development of the MPEI theory of change supported this ongoing assessment of the overall success of MPEI.

The first step to explore the feasibility of such a study was taken in 2014 by Moi Becroft and Fiona Cram, who met with four MPEI providers that had signalled an interest via an initial conversation. The discussion centred on what the focus of the study might be, and how such a study might fit with their initiatives. A meeting was also organised with the MPEI evaluators to gain their input, and a further meeting with the four providers helped tease out ideas as to what the study might explore.

The upshot of this initial engagement was a desire for the longitudinal evaluation study to focus on students' educational progress and achievement, alongside their overall wellbeing. It was felt that parents/carers should be asked about their involvement with and support of their children's learning, and how their family more generally was faring. The scope should include the MPEI providers as evolving change agents, and the role of the wider community in supporting better outcomes for Māori and Pacific children and young people.

Based on these discussions, a scoping document and funding recommendation was prepared and in late 2014 Foundation North agreed to resource a longitudinal MPEI evaluation study. Other than a desire to track students to see whether early gains were sustained over time, Foundation North left the detailed study focus open, to be co-designed with MPEI providers. This process is described next.

\section{Collaborative study development}

Once funding was approved the goal was to collaboratively develop the study purpose, focus, and design with the MPEI providers. During the initial months of this activity two more MPEI providers signalled their desire to be involved and were invited to join the collaboration. ${ }^{4}$ A small study team was created involving the Centre for 
Social Impact, Foundation North, and the University of Auckland. The team has Māori and Pacific study leads and a Pākehā coordinator. Dr Reremoana Theodore from the University of Otago's National Centre for Lifecourse Research is an adviser to the study, as is Frances Hancock, a narrative researcher and writer who captured the early journey and stories from the first phase of MPEI (MPEI Contributors \& Hancock, 2012b).

Throughout 2015-16 the study team met with the MPEI providers individually and collectively (via three joint meetings) to build the focus and methodology for the study. Separate hui were held with parents and carers from two schools in Glen Innes involved with Manaiakalani, to test the proposed study focus and to ask what the study team needed to know, ask, or find out about as part of the study. Progress on the development of the study has also been reported to the Māori and Pacific Committee of Foundation North, and to the CEO, Jennifer Gill.

All those canvassed have been interested and enthusiastic about the idea of a longitudinal evaluation study. The providers are interested in the paths their students take, including their learning and employment outcomes. They have an intense interest in how the experience that each student and family has with them plays out over time, and in which elements of that experience have the greatest influence. Other joint areas of interest for providers include:

- what school responsiveness and effectiveness look like for Māori and Pacific families

- the role and influence of families on children's learning and development

- understanding the challenges and realities families face and how they impact on children

- what families are doing that supports the wellbeing of children 
- how to keep connected to former students and track their progress over time, through digital or other means

- using the study to meet information requirements of funders and stakeholders.

The collaborative process to design the study centred on four key areas: 1) study kaupapa (agenda) and focus; 2) study values, principles and approach; 3) study participants; and 4) methods. Each of these four elements is described next.

\section{Study kaupapa and focus}

"Parents need to know their kids are succeeding. There is so much deficit thinking upon Māori and [Pacific people], we need to reach out" (Pt England Primary School parent).

Early on in our engagement with MPEI providers, the Principal of Pt England Primary School and co-founder of Manaiakalani, Russell Burt, suggested that the study could focus on what "success" looks like for Māori and Pacific families; what is going right for Māori and Pacific learners; and what is functioning in families that supports children to learn and flourish on their own terms. This was supported by feedback from Associate Professor Tony Trinick (University of Auckland) through his involvement with an MPEI provider.

To test how a focus on self-defined success would sit with families, families attending two school meetings in Glen Innes (Pt England Primary and Glen Taylor School) were asked to respond to five questions: How would you describe success for your family? What would your family success look like 10 years from now? What are some of the steps on the way to this future success? Without willing families, we will not be able to tell this valuable story; how should we invite families to join this study? What are some key things our researchers need to know, ask, or find out? This brainstorming exercise affirmed that families were enthusiastic about focusing on the success of their 
children and family, had clear ideas on what that success looked like now and in 10 years' time, and what they needed to do to achieve that success.

The elements of success that people identified included: a sense of belonging, being happy and healthy, being stable and having choices, sharing, receiving, and giving to others, attending school or university, being together, communicating well, being loving, connected, and supportive, having strong values, being adaptable, balanced and open, setting goals, being educated, achieving, and learning. Parents also shared some of the things we needed to know or find out about, including:

"What's going right, how do we pass this on successfully to our struggling parents/ community?" (Parent)

"The daily barriers families face, what families value and need, what families do for fun, the education of parents and how this impacts on how kids learn." (Parent)

"Take the time to listen to people's story." (Parent)

A focus on self-defined success and on what is going right for Māori and Pacific students and families had an energising effect across those involved in the study. Its positive focus appealed, as did the opportunity it would give people to reflect on and define for themselves what success looks like to them, and what gives rise to this success. However, during joint hui with providers there was some debate over placing the notion of success at the heart of the study. The issues were that "success" can imply having an end-point or destination; it can limit the idea of learning and of life as a journey; and can pigeonhole people into being a success or not, according to how success is framed. "Success" can also be appropriated in the education system and other mainstream contexts to have particular or narrow meanings, such as National Standards achievement, academic or financial 
success. Ultimately, it was considered that the concept of 'success' would make sense to families and students, and that it should be self-defined by study participants.

After these rounds of provider discussions, debate within the project team, and discussion with Foundation North's Māori and Pacific Committee, the agreed purpose of the MPEI longitudinal evaluation study is to examine success as Māori and as Pacific students and families, in terms of:

- what success looks like

- what most supports and hinders success

- how this success can be supported at individual, family, educational, and community levels.

In addition to this core inquiry, in each round of interviews additional flexible themes will be explored, based on what MPEI providers, families, and students want to learn more about. In 2017, the themes were:

- what families are doing or can do to support their children to do well at school

- family perceptions of the school their child attends and what is effective in schools for Māori and Pacific learners.

\section{Study values, principles, and approaches}

Embedded in the design and development of the first phase of MPEI were "principles of collaboration, co-design, and community development” (McKegg, et al., 2016, p. 127), and a relational approach nurturing trust and faith among people. It was clear from discussions with the MPEI providers that the study needed to retain these principles, as well as build off the knowledge, commitments, and capacity already held by providers. In addition, the collaborative design of the study brought to the fore other important values and principles, including the following. 
- Kaupapa Māori and Pacific cultural values, knowledge, protocols, practices, and processes must explicitly drive and infuse the study.

- The study needs to be strengths-based and empowering for those involved.

- Framing cultural identity openly and giving people permission to describe the role of cultural identity fully is important. The study should link with other work nationally on cultural identity, success, and education (see for e.g., Anae (2010); Borell (2005); Macfarlane et al., (2014); McNaughton (2011); Milne (2013); Siataga (2011); Tongati'o (2010); Wendt Samu (2015).

- The study needs to enrich the knowledge of participants and communities.

- Study findings should be actively used to achieve positive change with and for Māori and Pacific communities.

The study aims to continue the MPEI approach and deliver on the principles above. It is an affirming inquiry, and it should be noted that taking a positive approach does not prevent interviewees from talking about less positive or negative aspects of their lives (Cram, 2010). MPEI providers were asked what it would look like if the MPEI vision, approach, and kaupapa Māori and Pacific cultural values and protocols truly underpinned the longitudinal evaluation study. Their responses are presented in Table 1 below.

\begin{tabular}{|l|l|}
\hline \multicolumn{1}{|c|}{ Method } & \multicolumn{1}{c|}{ Description } \\
\hline Family interview & $\begin{array}{l}\text { A 2-hour face-to-face recorded interview with the family and student, } \\
\text { at their home or a place of their choosing. }\end{array}$ \\
\hline In-depth stories & $\begin{array}{l}\text { Around 6-12 in-depth family stories from across the study population } \\
\text { will be created in each round of engagement (1-2 families for each } \\
\text { MPEl provider), to illustrate core themes and a range of circumstances, } \\
\text { issues, and views. }\end{array}$ \\
\hline Visual/other methods & $\begin{array}{l}\text { From the second round of engagement, the potential for film, photo, } \\
\text { documentary, and other visual or alternative means of capturing } \\
\text { views, experiences, and participant stories will be explored. }\end{array}$ \\
\hline
\end{tabular}

Table 1. Core Longitudinal Evaluation Study Methods 


\section{Study participants}

In 2017, around 100 Māori and Pacific students and their families were invited to take part in the study. Each provider selected 20 families to invite, based on these criteria:

- Māori and/or Pacific students aged 8 to 16 years (at the start of the study)

- a range of family composition and learners

- families who are keen and willing to commit to a long-term study

- families who are open to the school or education provider sharing their stories about success

- students and families who have been with each MPEI project for at least 2 years, at the start of the study.

Families were invited to participate in the study by the MPEI provider, and willing families were followed up by community researchers recruited for this study. These researchers are the main point of contact for the families and students. The first round of family and student interviews occurred in 2017, resulting in 72 families being interviewed. A relatively quick second round of interviews in 2018/19 is planned, to engage people in the study and provide rich data in its early stages.

\section{Methodology}

The longitudinal evaluation study described in this article is one "where successive measures are taken at different points of time from the same respondents"; or a longitudinal cohort study (Cohen, Manion, \& Morrison, 2009, p. 212). This study has a qualitative bent, though quantitative measures will be recorded at each round of engagement with families and students. Qualitative longitudinal studies tend to involve in-depth interviews that involve returning to interviewees to measure and explore changes that occur over time, 
and the processes associated with these changes (Farrell, 2006; Holland, Thompson \& Henderson, 2006). In this study, there will be four "deep dives" across time, involving asking the same core set of questions each time (around ideas of success as Māori and as Pacific learners and families and what supports that), along with flexible additional themed inquiries.

During the development of the MPEI longitudinal evaluation study, relevant Aotearoa New Zealand longitudinal studies and other surveys were reviewed (see, for example, Poland \& Legge, 2005). The review focused on identifying potential measurement tools and questions that could be used to provide sources of comparative data. ${ }^{5}$ Research on Māori and Pacific success has also been reviewed, including Macfarlane and colleagues research (2014) on success as Te Arawa, and Maria Meredith's PhD research looking at Pacific fanau engagement in children's education in a digital age.

The core methods of the study for each round of engagement with families and students are summarised below in Table 2. This is a family centred study, and the core study method is a face-to-face in-depth, recorded interview with each family and student.

\begin{tabular}{|l|l|}
\hline \multicolumn{1}{|c|}{ Study Principles } & \multicolumn{1}{c|}{ Practices } \\
\hline $\begin{array}{l}\text { As Māori for Māori, and } \\
\text { as Pacific for Pacific }\end{array}$ & $\begin{array}{l}\text { Foundation North's Māori and Pacific Committee is the primary } \\
\text { governance body for the study. } \\
\text { Māori and Pacific leadership on the study project team. } \\
\text { MPEl providers play leadership and advisory roles. } \\
\text { Māori and Pacific specialist advice brought in to the study as required. } \\
\text { The study participants will all be Māori and/or Pacific. } \\
\text { The community researchers recruited to engage students and } \\
\text { families will be Māori and/or Pacific—they will also be drawn from the } \\
\text { communities of the MPEl participating projects. } \\
\text { Involvement of Māori and Pacific MPEl projects, community } \\
\text { researchers, and participants in sense making of the data and how it is } \\
\text { communicated. }\end{array}$ \\
\hline
\end{tabular}




\begin{tabular}{|l|l|}
\hline \multicolumn{1}{|c|}{ Study Principles } & \multicolumn{1}{c|}{ Practices } \\
\hline $\begin{array}{l}\text { Māori and Pacific cultural } \\
\text { values, knowledge, } \\
\text { and methodologies are } \\
\text { explicit }\end{array}$ & $\begin{array}{l}\text { A relational approach based on building relationships of trust, } \\
\text { integrity, respect, and humility. } \\
\text { A commitment to mutual enrichment, enhancing mana and } \\
\text { manaakitanga } \\
\text { Face-to-face'kanohi ki te kanohi'and talanoa methods. } \\
\text { Culturally responsive recognition of participants'time and appropriate } \\
\text { koha and reciprocity. } \\
\text { Development of family stories that are gifted to the families. }\end{array}$ \\
\hline $\begin{array}{l}\text { Building the knowledge, } \\
\text { skills, and capacity } \\
\text { of communities and } \\
\text { participants }\end{array}$ & $\begin{array}{l}\text { Recruitment and training of Māori and/or Pacific researchers } \\
\text { and language speakers, drawn as far as possible from the MPEl } \\
\text { participating communities. } \\
\text { Regular updates about the study and its findings to be distributed to } \\
\text { families and students. } \\
\text { Development of resources from study findings, to inform and resource } \\
\text { families as partners with schools in student learning and achievement. }\end{array}$ \\
\hline $\begin{array}{l}\text { Clear benefits for } \\
\text { participants and society }\end{array}$ & $\begin{array}{l}\text { Participants will be able to reflect on what "success" looks like to them, } \\
\text { on how they support their child's learning, be able to set family and } \\
\text { child focused goals, know they are helping other families and learn } \\
\text { how to better support their own. } \\
\text { Communities will better understand how to support Māori and Pacific } \\
\text { children and young people. } \\
\text { The findings will be used to advocate to policy makers, the education } \\
\text { sector, social services, government, and the nation to invest in } \\
\text { supporting Māori and Pacific students and families to succeed, to } \\
\text { benefit the nation. }\end{array}$ \\
\hline $\begin{array}{l}\text { Intentional social change } \\
\text { aspiration }\end{array}$ & $\begin{array}{l}\text { Profiling and sharing messages from the study with those able to } \\
\text { drive positive change. } \\
\text { The use of storytelling techniques via narratives and visual methods, } \\
\text { to influence change. } \\
\text { Supporting participants and communities involved to tell their stories } \\
\text { and advocate for change. }\end{array}$ \\
\hline
\end{tabular}

Table 2. Practices to Manifest Kaupapa Mãori and Pacific Cultural Values in Ngā Tau Tuangahuru

At each interview round, families will also be asked if they would be prepared to have their interview developed into a DVD or written "story" that will share key aspects of their journey, views, and realities. Families will be asked to review and approve these stories, which will be gifted to the family in film or written form and be used with their permission to share lived realities and exemplify themes from the interviews overall. These stories and potential film and visual 
methods continue the MPEI commitment to support people to speak for themselves.

Foundation North will also liaise with potential partners and funding collaborators to strengthen the study, and explore opportunities to influence change. Delivering messages from the study to policy makers and decision makers will be a priority for Foundation North and this will involve study participants and MPEI projects, as negotiated with and agreed by them. The study results from the first round of interviews are expected in 2018.

\section{Evaluative aspects of the study}

The longitudinal evaluation study will test and deepen the MPEI theory of change, particularly from students' and families' perspectives. In the MPEI theory of change, success as Māori and Pacific people (Kinnect Group \& Foundation North, 2016c, p. 7, also see Figure 1 above)was framed around: pride, sense of identity and wellbeing; engagement in wider whānau, community, and church life; leadership and service; and educational and economic success. The longitudinal evaluation study will explore where these features sit within Māori and Pacific student and family perspectives of success; what changes across ages and stages in terms of aspirations; and what supports and gets in the way of those aspirations over time.

Based on the MPEI evaluation, the areas of focus for the longitudinal study include:

- cultural confidence, pride and identity (e.g., confidence in Māori/ Pacific worlds as well as mainstream worlds and feeling good about being Māori/Pacific)

- whānau/family understanding and engagement (e.g., families feel welcome at school, participate in school activities, and support their children's learning at home) 
- attitudes and aspirations of students, teachers and families (e.g., career aspirations, rapport, expectations, and trust between students and teachers)

- student retention and engagement (e.g., students want to be at school, are happy to be at school, high attendance, staying in school longer)

- literacy and numeracy via school achievement results

- academic achievement, including National Standards data, National Certificates of Educational Achievement (NCEA) or Cambridge results, awards, and entry to tertiary education or other opportunities

- employment, training and further education (students/family members' progress to employment, training, or further education opportunities).

Participating MPEI providers will receive evaluative feedback on what students and families consider to be effective in supporting their children and young people as Māori and Pacific learners, and what else they could do in this regard.

As the participant sample is not representative of all Māori and Pacific student learners, the study findings will not be generalisable. Even so, this type of research is important as it: 1) aligns with governmental priorities; 2) takes a strengths-based approach; 3) helps to build an evidence base around what supports Māori and Pacific success; and 4) will enrich family, community, educational, and policy knowledge about how to support this success.

\section{Discussion}

The MPEI longitudinal evaluation study emerges from the bold investment of Foundation North in the Māori and Pacific Education Initiative, the hard work of pioneering Māori and Pacific-focused 
education providers, and the developmental evaluation of the first phase of the MPEI. This MPEI longitudinal evaluation study will support Māori and Pacific students and their families by focusing on their strengths, aspirations, hopes, and dreams and what brings those into being. It will provide a counter story to mainstream deficit accounts of Māori and Pacific educational underachievement. Melinda Webber, for example, notes that one of the biggest issues emerging from research into success as Te Arawa, is Māori children and young people internalising negative messages that they hear, for example about themselves as Māori, about Māori educational achievement or about Māori in general (Webber, 2016).

There are several internationally renowned longitudinal studies in New Zealand. Until recently, the importance of these studies and their findings, in terms of understandings of human development, were primarily recognised by academic audiences and more recently policy makers. Recently however, national public awareness of longitudinal studies and their value has been raised in Aotearoa by the 2016 national television screening of the Why Am I? documentary series (TVNZ, 2016). This series outlined key findings from the Dunedin Multidisciplinary Health and Development Study ("Dunedin Study"), some of which are having a global impact. The MPEI longitudinal evaluation study leverages off other longitudinal studies' findings, questions, and methods. Most national longitudinal studies to date have been primarily quantitative. By using qualitative methods, the MPEI longitudinal evaluation study will be able to provide an in-depth analysis of what success looks like for Māori and Pacific students and families, over time.

Several key ingredients have led to the emergence of this longitudinal evaluation study. The first is the pivotal role of Foundation North staff member Moi Becroft, who has been an anchor for MPEI since it was first conceptualised. Having observed the journey of 
MPEI and its provider organisations over almost 10 years, Moi is deeply committed to the potential of this study to share the realities and views of Māori and Pacific families and students, in ways that can influence change and support investment in those things that assist self-defined success. The relationships and trust held between Moi and the providers, her understanding of cultural values, relational way of working, and input to the shaping of the study were critical to getting the study off the ground.

A second key ingredient was starting with the providers and their communities before funding was approved by Foundation North, by checking in to see whether there was interest in this study and what its focus might be. A third positive factor has been the ability to undertake this collaborative design of the study in an unhurried way. This has allowed time for critical thinking and reflection and has avoided placing pressure on providers to commit more time than they can manage to the study.

Fourth, the commitment to having Māori and Pacific study leads, working closely with MPEI providers, involving highly skilled research advisers as required, and recruiting community researchers who can engage well with Māori and Pacific families and students, will enable the study to produce valid findings. There is also immense value in having a cross-cultural, transdisciplinary research group holding the study (see for example Cram \& Phillips, 2012).

Finally, our relationships with the MPEI providers involved in this study will allow us insight into any substantive changes that may occur in their practice models. Such changes may signal an evolution or possibly a deviation from the MPEI theory of change (Figure 1) that we will need to be aware of going forward. Although this is no substitute for an ongoing, intimate evaluation relationship with each initiative, it fits with our goal of providing insights into the longitudinal outcomes of MPEI overall. 
As well as a vehicle for advocacy and social change, Foundation North and the Centre for Social Impact intend to use the MPEI longitudinal evaluation study to connect researchers and evaluators and foster social change in Māori and Pacific education and social development. To this end, they will host hui and events from time to time, to connect, network, share activity, and identify opportunities to support one another, advocate, and collectively make a difference.

MPEI is innovative for philanthropy in Aotearoa, demonstrated again via Foundation North's decision to resource a study addressing a goal it believes in—raising Māori and Pacific educational achievement, by giving ongoing effect to its vision for MPEI: Mā tātou anō tātou e kōrero-We speak for ourselves.

\section{Acknowledgements}

1. The funding for the project described in this article comes from Foundation North's Māori and Pacific Education Initiative. 2. Rachael and Fiona are working with the Centre for Social Impact to undertake this study. 3. We are most appreciative of the reviewer feedback we received for this article.

\section{Notes}

1 The providers funded included schools (Sylvia Park School and its Mutukaroa Programme), education initiatives and future partnership schools (Rise UP Trust and He Puna Marama Trust), programmes linked to schools (High Tech Youth, C-Me Mentoring, Ideal Success and Manaiakalani), and tertiary education related initiatives via Unitec, Māori into Tertiary Education (MITE), and StarPath.

2 The experience and insights from this evaluation are described in an edited collection of developmental evaluation exemplars (Patton, McKegg \& Wehipeihana, 2016).

3 The Value for Investment Evaluation Report for MPEI (Kinnect Group \& Foundation North, 2016b) estimates that $\$ 29$ million net public and private attributable benefit to its graduates and society will occur from one MPEI project alone within 5 years (C Me Trades at School, which is now called Oceania Careers Academy). 
4 The six providers that took part in the development of this study were: He Puna Marama Trust in Whangarei, Rise Up Trust in Otahuhu, Manaiakalani in Tamaki (involving up to five of the 13 schools in the Manaiakalani cluster), Oceania Careers Academy in Mangere (which emerged out of C-Me Mentoring), Sylvia Park School in Mt Wellington and High Tech Youth, which has outreach programmes across New Zealand and the Pacific. Although involved in the discussions about the study, High Tech Youth had to withdraw just prior to the beginning of data collection. We have chosen to leave them in this list because of their early collaboration.

5 This review of studies included the following birth cohort studies: the Dunedin Study, including three of its sub-studies - Family Health Study, Parenting Study and Next Generation Study looking at the teenage children of Dunedin Study participants; the Christchurch Health and Development Study; the Pacific Islands Families (PIF) Study; and the Growing up in New Zealand Study (Morton, et al., 2012). Other studies reviewed included the Best Outcomes for Māori/Te Hoe Nuku Roa Study, the Competent Children Project, the Survey of Families, Income and Employment (SOFIE), and the Graduate Longitudinal Study New Zealand. Relevant questions in the National Census and other national surveys such as 2013 Te Kupenga, a Statistics New Zealand Survey of Māori Wellbeing, were also identified.

\section{References}

Anae, M. (2010). Research for better Pacific schooling in New Zealand: Teu le va-a Samoan perspective. Mai Review, 1, 1-24.

Borell, B. (2005). Living in the city ain't so bad: Cultural diversity of South Auckland rangatahi. Unpublished master's thesis, Massey University. Retrieved from http://mro.massey.ac.nz/xmlui/handle/10179/5812

Centre for Social Impact. (2014). New Zealand's centre of excellence for enabling social impact. Retrieved from www.centreforsocialimpact.org.nz/

Cohen, L., Manion, L., \& Morrison, K. (2009). Research methods in education (6th ed.). London, United Kingdom: Routledge.

Cram, F. (2010). Appreciative inquiry. Mai Review, 3, Article 4.

Cram F., \& Phillips, H. (2012). Claiming interstitial space for multicultural, transdisciplinary research through community-up values. International 
Journal of Critical Indigenous Studies, 5(2), 36-49.

Farrell, S. (2006). What is qualitative longitudinal research? Papers in Social

Research Methods, Qualitative Series 11. London, United Kingdom:

London School of Economics and Political Science Methodology Institute.

Retrieved from http://www.lse.ac.uk/methodology/pdf/QualPapers/

Stephen-Farrall-Qual\%20Longitudinal\%20Res.pdf

Fletcher, J., Parkhill, F., Fa’afoi, A., Tufulasi Taleni, L., \& O’Regan, B.

(2009). Pasifika students: Teachers and parents voice their perceptions of what provides supports and barriers to Pasifika students' achievement in literacy and learning. Teaching and Teacher Education, 25(1), 24-33.

Foundation North. (2016a). Catalysts for change. Retrieved from https://www. foundationnorth.org.nz/funding/what-we-fund/catalysts-for-change/

Foundation North. (2016b). Mãori and Pacific education initiative.

Retrieved from https://foundationnorth.org.nz/how-we-work/ māori-pacific-education-initiative/

Foundation North. (2017). Enabling innovation to turn the tide on the environmental degradation of the Hauraki Gulf. Retrieved from http:// www.giftofthegulf.org.nz

Gorinski, R. \& Abernethy, G. (2007). Māori student retention and success: Curriculum, pedagogy and relationships. In T. Townsend and R. Bates (Eds.), Handbook of teacher education: Globalization, standards and professionalism in times of change (pp. 229-240). Netherlands: Springer.

Gorinski, R. \& Fraser, C. (2006). Literature review on the effective engagement of Pasifika parents and communities in education. Report to the Ministry of Education: Wellington. Accessible at http://thehub.superu.govt.nz/sites/ default/files/42375_piscpl-lit-review_0.pdf.

Hancock, F. (2009). Mãori and Pacific Education Initiative thinkpiece. Auckland: ASB Community Trust.

Holland, J., Thomson, R., \& Henderson, S. (2006). Feasibility study for a possible qualitative longitudinal study: A discussion paper. Report to the ESRC. London: London South Bank University. 
Kinnect Group \& Foundation North. (2016a). Kua ea te whakangao: Mãori and Pacific Education Initiative - Value for investment evaluation report. Auckland: Foundation North. Retrieved from https://do6qmrbufqcd2. cloudfront.net/1003/fn-mpei-evaluationreport-f-spreads-ilovepdfcompressedcompressed-min-min-min-min.pdf

Kinnect Group \& Foundation North (2016b). What have we learned about Mãori and Pacific educational success? Foundation North's Mãori and Pacific Education Initiative. Foundation North Learning Series 1. Auckland: Foundation North. Retrieved from https://do6qmrbufqcd2.cloudfront. net/1002/fn-mpeilearningseries1-fspreadscompressedcompressed-min.pdf

Kinnect Group \& Foundation North (2016c). What have we learned about evaluating high engagement funding for Māori and Pacific? Foundation North's Mãori and Pacific Education Initiative. Foundation North Learning Series 3. Auckland: Foundation North.

Macfarlane, A.H., Webber, M., Cookson-Cox, C., \& McRae, H. (2014). Ka awatea: An iwi case study of Mãori students' success. Report commissioned by Ngā Pae o te Māramatanga, Auckland.

McKegg, K., Wehipeihana, N., Becroft, M., \& Gill, J. (2016).

Developmental evaluation's role in supporting community-led solutions for Māori and Pacific young people's educational success, The Foundation North Māori and Pacific Education Initiative. In M. Q. Patton, K. McKegg, \& N. Wehipeihana (Eds), Developmental evaluation exemplars: Principles in practice. New York, NY: The Guilford Press.

McNaughton, S. (2011). Designing better schools for culturally and linguistically diverse children: A science of performance model for research. New York, NY: Routledge.

Milne, B. A. (2013). Colouring in the white spaces: Reclaiming cultural identity in whitestream schools. Unpublished doctoral dissertation, University of Waikato, Hamilton.

Ministry of Education. (2013a). Ka hikitia: Accelerating success 2013-2017. Wellington: Ministry of Education. 
Ministry of Education. (2013b). Pasifika education plan 2013-2017. Wellington: Ministry of Education.

Morton, S., Atatoa Carr, P.E., Grant, C.C., Lee, A.C., Bandara, D.K., Mohal, J., ... Wall, C.R. (2012). Growing up in New Zealand: A longitudinal study of New Zealand children and their families. Report 2: Now we are born. Auckland: Growing Up in New Zealand. Retrieved from http://www.superu.govt.nz/sites/default/files/Now\%20we\%20are\%20 born.pdf

MPEI Contributors, \& Hancock, F. 2012a. He akoranga he aratohu: Maori and Pacific Education Initiative, lessons to guide innovative philanthropy and social practice. Auckland: ASB Community Trust. Retrieved from https:// do6qmrbufqcd2.cloudfront.net/1003/he-akoranga-he-aratohu.pdf

MPEI Contributors, \& Hancock, F. (2012b). Nga maumaharatanga: Māori and Pacific Education Initiative-Our journey of forging philanthropic innovation together. Auckland: ASB Community Trust. Retrieved from https://do6qmrbufqcd2.cloudfront.net/1002/nga-maumaharatanga.pdf

National Institute for Public Health \& Mental Health Research. (2017). Pacific Islands families study. Retrieved from https://niphmhr.aut.ac.nz/ research-centres/centre-for-pacific-health-and-development-research/ pacific-islands-families-study

Poland, M., \& Legge, J. (2005). Review of New Zealand longitudinal studies. Wellington: Families Commission.

Poulton, R., Moffitt, T.E. \& Silva, P.A. (2015). The Dunedin

Multidisciplinary Health and Development Study: Overview of the first 40 years, with an eye to the future. Social Psychiatry and Psychiatric Epidemiology, 50(5), 679-693.

Siataga, P. (2011). Pasifika child and youth well-being: Roots and wings. In P. Gluckman (Ed.), Improving the transition: Reducing social and psychological morbidity during adolescence (pp. 153-167). Wellington: Office of the Prime Minister's Chief Science Officer. 
Sylvia Park School. (2017). Mutukaroa: Home-school partnership. Retrieved from http://www.sylviapark.school.nz/home-school-partnership

Tongati'o, L. (2010). Ko e fanā fotu': Success in motion, transforming Pasifika education in Aotearoa New Zealand 1993-2009. Unpublished doctoral dissertation, University of Canterbury, Christchurch. Retrieved from http://ir.canterbury.ac.nz/handle/10092/4948.

TVNZ. (2016). Why am I? Retrieved from https://www.tvnz.co.nz/ ondemand/why-am-i

Webber, M. (2016, June). Presentation to MPEI Longitudinal Study hui, Auckland.

Wendt Samu, T. (2015). The 'Pasifika Umbrella' and quality teaching: Understanding and responding to the diverse realities within. Waikato Journal of Education - Te Hautaka Matauranga o Waikato, Special 20 $0^{\text {th }}$ Anniversary Collection, 129-140.

\section{The Authors}

Rachael Trotman (Weave), Dr Fiona Cram (Katoa Ltd), Dr Tanya Samu (University of Auckland), Moi Becroft (Foundation North), Dr Reremoana Theodore (University of Otago), Dr Tony Trinick (University of Auckland), in association with Pt England Primary School, Manaiakalani, Sylvia Park School, Rise UP Trust, He Puna Marama Trust, Oceania Careers Academy and High Tech Youth.

Email: Rachael.Trotman@csinz.org 